\title{
Cities, Mobility and Climate Change
}

\author{
David Banister \\ Professor of Transport Studies \\ Director of the Transport Studies Unit and Acting Director of the Environmental Change \\ Institute \\ School of Geography and the Environment \\ Oxford University \\ david.banister@ouce.ox.ac.uk
}


Abstract: Societies gain enormous benefits from travel, as economies have become more globalised and as the new communications infrastructure allows international networking and travel at a low cost. There has been a true internationalisation of all activities, and travel forms an essential part of that process. However, this mobility is fuelled by carbon, and there is clear scientific agreement that carbon emissions are affecting the global climate with irreversible long term consequences. Transport is the one sector where a reduction in energy use and emissions is proving to be extraordinarily difficult to achieve despite some success in urban areas. This paper focuses on cities, mobility and climate change, highlighting recent trends in both developed and developing countries. It is argued that the current situation is unsustainable, and that transport must contribute fully to achieving carbon reduction targets. An alternative is presented, based on the sustainable mobility paradigm (Banister, 2008) that looks at ways to reduce the need to travel in cities. The belief that high mobility and technology provides the solution is misplaced, as technological innovation can only get us part of the way to sustainable transport, and this may facilitate more travel. There are opportunities for cities to switch to low carbon transport futures, where vision and action are based on a combination of economic, planning and technological innovations working in mutually supporting ways. Potentially, the future is bright for low carbon transport in cities, but the real question is whether there is the commitment and leadership to follow such a path.

\section{Introduction}

There are enormous benefits from travel, as economies have become more globalised and as the new communications infrastructure allows international networking at low cost. People's aspirations and expectations have been increased through media coverage of world events, through more educational and leisure opportunities, and through increasing wealth. There is a true internationalisation of all activities, and travel forms an essential part of that process. To counter that optimism is the evidence that we now live in the carbon society, and that carbon emissions are affecting the global climate with irreversible long term consequences. Transport is the one sector where such a reduction in energy use and emissions is proving to be extraordinarily difficult to achieve.

In urban areas, there are many good examples of reductions in energy use in transport, principally through demand management (pricing, parking and access control, congestion charging), investment in public transport, priority for walking and cycling, and a range of soft measures designed primarily to reduce the use of single occupancy cars. In addition planners have been active in creating high quality local neighbourhoods, including innovative designs for housing and mixed use developments, and the concentration of development around public transport accessible locations. In all cases, the intention is to reduce the need to travel (particularly by car), to encourage greater use of public transport (and walking and cycling), and to reduce travel distances. The key here is to provide quality, with easy access to local services and facilities, so that people do not need to travel long 
distances. There are positive signs that city living is becoming 'fashionable' and that sustainable lifestyles are being adopted by many people (Banister, 2005).

This paper focuses on cities, mobility and climate change, highlighting recent trends in both developed and developing countries. It is argued that the current situation is unsustainable, and that transport must contribute fully to achieving carbon reduction targets. An alternative is presented, based on the sustainable mobility paradigm (Banister, 2008) that looks at ways to reduce the need to travel in cities. The belief that high mobility and technology provides the solution is misplaced, as technological innovation can only get us part of the way to sustainable transport, and this may facilitate more travel. Evidence for making much stronger use of the planning and land development policies in combination are cited for cities in both developed and developing countries, and the argument is made for the use of all available policy levers in mutually supporting ways, including economic, planning and technological opportunities. Potentially, the future is bright for low carbon transport in cities, but the real question is whether there is the commitment and leadership to follow such a path.

\section{The Reality in the $E U$}

In most EU cities, there are some indications that modest change in behaviour has taken place. The real challenge is not the acceptance of the strong links between mobility and climate change, but the imperative for substantial behavioural change. The scale of the problem has been totally underestimated, and the actions being taken by governments at all levels are not addressing the seriousness of the issues. Even the actions taken by the most environmentally aware individuals are not sufficient, as it has proved very difficult to stabilise the level of carbon emissions from transport, let alone reduce them (Table 1). Since 1990, there has been a steady increase in energy, emissions and travel in the EU27, and the pattern seems to suggest that the increase in energy and emissions is growing at a faster rate over this period than travel.

Even though schemes have been implemented to reduce the use of the car in cities and to make its use more efficient elsewhere, there has still been a substantial growth in travel distance, as cities have spread and as the desire for low density car based lifestyles has become dominant. The technology has not kept pace with the growth in car based travel, and even a substantial shift to more efficient vehicles and alternative fuels will not address the problems fully. Over the next 25 years, it has been estimated that the maximum (possible) contribution of technological innovation to reducing $\mathrm{CO}_{2}$ emissions in the transport sector in the $\mathrm{UK}$ would be about $21 \mathrm{MtC}$ (to 2030) (Banister and Hickman, 2006). This is about half the levels required to achieve a $60 \%$ reduction, equivalent to the targets set by the IPCC over the longer period to $2050^{1}$ (IPCC, 2001 and 2007).

Such a change would require the 'average' cars to have an emissions profile of 90 $\mathrm{gCO}_{2} / \mathrm{km}$, which is less than the current benchmark level of $104 \mathrm{gCO}_{2} / \mathrm{km}$ (Toyota Prius and Citroen $\mathrm{C} 1$ ), with half the fuel that is still needed by these vehicles being sourced from second generation biofuels. The current average level of emissions of new cars in the UK (2005) is $169 \mathrm{gCO}_{2} / \mathrm{km}$ (SMMT, 2006). Similar changes would

\footnotetext{
${ }^{1}$ Note that the $60 \%$ reduction figure is that required by the IPCC to achieve the stabilisation of carbon emissions by 2050, but brought forward to 2030 (IPCC, 2007 and Stern, 2006). The UK government has set itself an $80 \%$ reduction target by 2050 , so this figure is consistent (Committee on Climate Change, 2008). It also assumes that transport should take a 'fair' share of the target reductions.
} 
be required in all EU countries. Massive investment would be required in changing production processes for the new super efficient cars, in sourcing substantial quantities of alternative fuels, and in giving incentives to industry and individuals to use these new vehicles. Perhaps the only way to achieve such a change would be to switch to electric city vehicles, but even here there would need to be a new support infrastructure, and the power would have to be generated from renewable sources.

Significant reductions of $\mathrm{CO}_{2}$ emissions in transport in the EU can only be achieved through behavioural change. There is little sign that people are aware of the scale of the challenge, or prepared to make the necessary changes. Globally, carbon emissions per capita are about $4.37 \mathrm{tCO}_{2}$ (2006) $\left(1.07 \mathrm{tCO}_{2}{ }^{2}\right)$, but the EU27 average is about $9.28 \mathrm{tCO}_{2}\left(2.53 \mathrm{tCO}_{2}\right)$ and the US figure is $19.45 \mathrm{tCO}_{2}\left(6.80 \mathrm{tCO}_{2}\right)$. The stabilisation targets mean that the average per capita level should be under $2 \mathrm{tCO}_{2}(2050)(0.75$ $\mathrm{tCO}_{2}$ ), much less than the current EU or US levels. It is also lower than the current level of $4.07 \mathrm{tCO}_{2}$ for China $\left(0.45 \mathrm{tCO}_{2}\right)$ and about double the current level of 1.07 $\mathrm{tCO}_{2}$ in India $\left(0.10 \mathrm{tCO}_{2}\right)$. This means that those countries currently producing more than the average levels of carbon emissions should be making an even greater contribution to the overall reduction target. The EU and the US should be leading the move towards contraction and convergence on this 'stabilisation' target (Meyer, 2001). Transport can and should play a major part in achieving the target.

\section{The Global Perspective}

In addition to the denial of the scale of change required, there are other difficulties in achieving sustainable transport. The US produces over $21 \%$ (2006) of the carbon emissions from energy (including transport), yet it is not part of any international agreement to reduce its emissions (EC DG Energy and Transport, 2008). Over the last ten years it has increased its $\mathrm{CO}_{2}$ emissions by $14 \%$, with global levels of $\mathrm{CO}_{2}$ increasing by $24 \%$ (1995-2005). Although only 5\% of the world's population live in the US, it has $30 \%$ of the cars and produces $45 \%$ of global car based $\mathrm{CO}_{2}$ emissions (DeCicco and Fung, 2006). It is crucially important that the US is fully engaged in the international debates about reducing levels of carbon emissions. The American Recovery and Reinvestment Act (2009) has allocated more than $\$ 80$ billion to the generation of renewable energy, investment in clean technology, advancing vehicle and fuel technologies, and building a smarter electric grid, and there are new efficiency standards for cars and trucks ${ }^{3}$. It is only very recently that the US motor industry seems to have become more aware of the need to produce a range of fuel efficient vehicles.

The global power structure is also changing, as has been seen at the Copenhagen Climate Change summit (COP15, December 2009), where for the first time China, India, Brazil and South Africa (the BASIC countries) have played a key role in determining the nature of the 'Accord' and the scale of the financial support for the poorer nations ${ }^{4}$. But there were no binding commitments made, and transport was not

\footnotetext{
2 The figures in brackets give the estimated levels of carbon dioxide emissions from the transport sector.

${ }^{3}$ The National Fuel Efficiency Policy (2012-2016) requires an average fuel economy standard of 35.5 mpg in 2016, and will save 1.8 billion barrels of oil over the life of the programme. The fuel economy gain averages more than 5 percent per year and will result in a reduction of approximately 900 million metric tons in greenhouse gas emissions.

${ }^{4}$ The COP15 Accord can be downloaded http://www.denmark.dk/NR/rdonlyres/C41B62AB-46884ACE-BB7B-F6D2C8AAEC20/0/copenhagen_accord.pdf
} 
mentioned either at the summit or in the 'Accord', even though this sector accounts for more than $23 \%$ of energy related global GHG emissions (Ribeiro, et al., 2007).

The outlook is brighter at the city level, as many local governments have taken on a leadership role in addressing the transport problems as they relate to carbon emissions, but there is considerable variation between cities. For example, more than half the total energy consumption in Mexico City, Hong Kong and Cape Town is transport based (UN Habitat, 2008), whilst the level in many European cities (for example, London and Paris) is about a quarter. This reflects the different strategies adopted by city planners over the recent past, such as promoting the use of the car through investment in roads and free parking, to demand management and constraints on the use of the car, and investment in local facilities and in public transport.

The politics are much wider than just the transport elements, as there are substantial income differences within and between cities, and not all people have access to transport. The UN Habitat (2008) review of world cities placed Beijing as being the most equal city in Asia (Gini coefficient ${ }^{5}$ 0.22), but Hong Kong (also in China) has a much higher level of inequality (Gini coefficient 0.53 ). Recent analyses suggest that India is undergoing an inequality trend somewhat similar to that of China as a result of liberalisation and globalisation. In 2002, the income gain in the richest 10 per cent of the population was about 4 times higher than the gain of the poorest 10 per cent (UN Habitat, 2008). Investment in most transport infrastructure and services benefits the rich and not the poor.

\section{Mega-Cities and Sustainable Transport}

Urban living will be at the centre of most activity, as over $50 \%$ of the world's population are now classified as urban dwellers (2005). There is a clear expectation that this figure will increase to $70 \%$ by 2050 . These levels of urbanisation are already apparent in Europe, North America and Latin America (UN Habitat, 2008). Globally, the rate of urbanisation is now 3 million per week (UN Habitat, 2008). Mega-cities (population over 10 million) are all characterised by high population growth, both from natural increase and through inward migration, and a huge expansion in the urban area with substantial new requirements for both housing and jobs. The rate of increase in the supply of new infrastructure will never match the growth in demand.

These cities have tremendous potential for growth and will be the powerhouses of the world economy over the next decades, but they are also centres for potential unrest, as there is substantial inequality and poverty (UN Habitat, 2008). The challenges for governments are daunting with little space for expansion in the original cities, so there is extensive urban sprawl with increased distances between where the people live, their jobs and other facilities. The concept of single centred cities is becoming less relevant with the growth in mega-cities, as they are rapidly developing as polycentric urban agglomerations, often absorbing other smaller cities in the process.

There is a fundamental difference between the priorities in high income cities, where the main concerns are over levels of pollution and consumption related burdens, and those in low income cities, where the concerns are more short term and health related.

\footnotetext{
${ }^{5}$ The Gini coefficient is the most widely used measure to determine the extent to which the distribution of income or consumption among individuals or households deviates from a perfectly equal distribution. A Gini coefficient of 0 indicates perfect equality and a Gini coefficient of 1 indicates perfect inequality. http://www.scribd.com/doc/328232/United-Nations-Gini-Coefficient
} 
Their requirements include clean water, electricity, waste management and sanitation. All cities contribute to global emissions, but the desire for economic growth seems to be overwhelming, and this imperative often takes precedence over other priorities, and the net effect is a continuing growth in local emissions $\left(\mathrm{NO}_{\mathrm{x}}, \mathrm{CO}, \mathrm{HC}, \mathrm{SO}_{2}\right.$, $\mathrm{PM}_{10}$, and $\left.\mathrm{PM}_{5}\right)$ and global emissions $\left(\mathrm{CO}_{2}\right)$. The high income cities have the opportunity to substantially reduce emissions through investment in clean technology and much greater energy efficiency, including a switch to low carbon energy. For the low income cities, the challenges are even greater, as they have other pressing social needs to address, but even here there are opportunities to switch to efficient low carbon energy sources.

There are good examples where development has been seen as investment, with the basic infrastructure being provided as part of the urbanisation process, as in Guangzhou City (Pearl River). Conversely, higher densities can be achieved through compactness and integrated approaches that combine investment in high capacity public transport and development, as in Hong Kong or Singapore (around their metro systems) or in Curitiba (around its bus rapid transit system). Strong city level governance is essential, where there is a clear vision about the future of the city, and where there is both the power and resources for action. But above all, there is a need for leadership and for all stakeholders to engage with the process of city-building, so that responsibilities and actions are both supported and implemented effectively. This is the only way to move towards the sustainable city. The alternative is one of weak governance, where there is no direction and the consequences are huge sprawling divided cities - this is the inefficient and unsustainable city.

In Europe, there are no mega-cities, the possible exception being London, where the city region has a population of 15 million ( $25 \%$ of national population) and $40 \%$ of the GDP. The key concerns here are quality and sustainability that cover equality of opportunity, and access to services and facilities, as well as high environmental standards. Here, the growth rates are modest and there are strong governance structures that encourage order, priority for people, polycentric urban form (London is a city of villages), and the full integration of land use and transport.

Many of the World's great cities are located on the coast or along the major rivers, as historically they have been centres of trade. But these locations are now prone to flooding, caused by storm surges and high winds, and accentuated by global warming $\left(+2^{\circ} \mathrm{C}\right)$ and sea level rise ${ }^{6}$. About $40 \%$ of the World's cities (1-10 million) and 15 of the 20 mega-cities lie on the coast. Their vulnerability to flooding has been substantially increased, and some have taken action to reduce the potential impacts, but 40 million or $10 \%$ of the total population are exposed to a 1 in 100 year coastal flood event, and this will rise to 150 million in 2070 (Table 2 and Nicholls et al., 2008). It is proposed that apart from upgrading protection and infrastructure to handle such events, land use planning should be used to reduce vulnerability for new developments and selective relocation of existing city areas should be considered. For example, London's flood barrier was built (1974-1983) at a cost of ( $£ 1300$ million in 2001 prices: $\$ 2000$ million) to prevent flooding from high tides and sea surges for the '100 year event'. Between 1986 and 1996, the barrier was raised 27 times, but in

\footnotetext{
${ }^{6} \mathrm{CO}_{2}$ concentrations are currently about $385 \mathrm{ppmv}$ and with other greenhouse gases being included, this value increases to $430 \mathrm{ppmv} \mathrm{CO}_{2} \mathrm{e}$ (2009). A level of 450 ppmv $\mathrm{CO}_{2} \mathrm{e}$ means that there is a 26$78 \%$ chance of exceeding $2^{\circ} \mathrm{C}$. A level of $550 \mathrm{ppmv} \mathrm{CO}_{2} \mathrm{e}$ means that there is a $63-99 \%$ chance of exceeding $2^{\circ} \mathrm{C}$. If global concentrations of greenhouse gases stabilise at 560 ppmv $\mathrm{CO}_{2} \mathrm{e}$, it is 'likely' that global mean surface temperatures will rise by $3^{\circ} \mathrm{C}$ above pre-industrial levels (Meinshausen, 2006).
} 
the period 1996-2006 it was raised 66 times. The expected property damage is estimated at $£ 30$ billion ( $\$ 50$ billion in 2001 prices) should the barrier be breached, and these financial costs do not include loss of life, health and income effects.

\section{The Sustainable Mobility Paradigm}

Sustainable mobility provides a new paradigm within which to investigate the complexity of cities, and to strengthen the links between land use and transport. The city will provide the location where most $(70-80 \%)$ of the world's population will live (2050). Empirical research in developed cities has concluded that the key parameters of a sustainable city are that they should be over 50,000 population, with medium densities (over 40 persons per hectare), with mixed use developments, and preference given to developments in public transport accessible corridors and near to highly public transport accessible interchanges where densities would be substantially higher (over 80 persons per hectare) (Banister, 2005). Such developments conform to the requirements of service and information based economies, and settlements of this scale would also be linked together to form agglomerations of polycentric cities, with clear hierarchies that would allow a close proximity of everyday facilities and high levels of accessibility to higher order activities (Hall and Pain, 2006).

Such urban forms would keep average trip lengths to below the thresholds required for maximum use of cycle and walk modes. It would also permit high levels of innovative services and public transport priority, so that the need to use the car would be minimised. Through the combination of clear planning strategies, cities would be designed at the personal scale to allow both high quality accessibility and a high quality environment. The intention is not to prohibit the use of the car as this would be both difficult to achieve and it would be seen as being against the notions of freedom and choice. The intention is to design cities of such quality and at a suitable scale that people would not need to have a car.

This alternative approach requires clear and innovative thinking about city futures in terms of the reality (what is already there) and the desirability (what we would like to see), and the role that transport can (and should) play in achieving these objectives. The sustainable city must balance the requirements along the physical dimensions (urban form and traffic) against those concerning the social dimensions (people and proximity), as illustrated in Table 3.

The sustainable mobility approach requires actions to reduce the need to travel (less trips), to encourage modal shift, to reduce trip lengths and to encourage greater efficiency in the transport system. A sustainable transport system means that we will travel less.

\subsection{Reducing the need to travel - substitution}

In its pure form this means that a trip is no longer made, as it has either been replaced by a non-travel activity or it has been substituted through technology, for example Internet shopping. The impact of information and communications technologies (ICT) on transport is complex, and on balance it seems that there is complementarity between these two factors (Banister and Stead, 2004). Although there is a large substitution potential, the relationships between transport and ICT seem to be symbiotic with a greater opportunity for flexibility in travel patterns, as some activities are substituted, whilst others are generated, and some replaced by fewer longer distance journeys (Lyons and Kenyon, 2003). There is also the possibility of carrying out a 'trip tour', where several activities are engaged in so that one longer 
journey replaces three or four shorter single activity trips. There is a net reduction in travel distance. Technology and networking in its widest form facilitates many different combinations of activities.

\subsection{Transport policy measures - modal shift}

Transport policy measures can reduce levels of car use through the promotion of walk and cycle and the development of the new transport hierarchy (Table 3). This can be achieved through slowing down urban traffic and reallocating space to public transport, through parking controls and road pricing, and through making it easier to use public transport. Demand management is effective in restricting access and reallocating space, and making better use of the available capacity. A much wider notion of the street is being created, as it is no longer only being considered as a road but also as a space for people, green modes and public transport. Creative use of that space at different times of the day or day of the week means also that new uses can be encouraged (e.g. street markets or play zones). Measures to encourage modal shift must be combined with strategies to make the best use of the 'released space', so that there is a net reduction in traffic (Banister and Marshall, 2000). This does not mean that more road capacity needs to be built, but that greater flexibility in its use is required and a greater proportion allocated to walk, cycle and public transport.

\subsection{Land use planning measures - distance reduction}

These measures address the physical separation of activities and the means by which distance can be reduced. The intention is to build sustainable mobility into the patterns of urban form and layouts, which in turn may lead to a switch to green modes and public transport. It is one area of public policy where intervention can take place, through increasing densities and concentration, through mixed use development, through housing location, through the design of buildings, space and route layouts, through public transport oriented development and transport development areas, through car-free development, and through establishing size thresholds for the availability of services and facilities (Section 6). The timescale over which sustainable mobility might be realised is similar to the turnover of the building stock (about 2 per cent per annum), but decisions on the location of new housing and retrofitting of existing buildings in new uses could have a dramatic effect on travel patterns, and these effects will impact over the lifetime of that housing.

\subsection{Technological innovation - efficiency increase}

The role of technology is still important, as it impacts on the efficiency of transport directly through ensuring that the best available technology is being used in terms of engine design, alternative fuels, and the use of renewable energy sources. The city car technology is likely to be based on a small highly efficiency ICE (Internal Combustion Engine) or an EV (Electric Vehicle or Plug-in Hybrid Vehicle). There are also considerable opportunities for new forms of public transport, for example in suburban areas where Demand Responsive Transport and even Personal Rapid Transit might play a key role. Technology could be used to provide a delivery service to local neighbourhoods or help organise car sharing schemes and car clubs. Holistic thinking on a low carbon city transport system is still embryonic.

Standards can also be introduced to reduce levels of noise and emissions at source, and measures can be taken to ensure that access to certain parts of the city are restricted to those vehicles that are environmentally cleaner than other vehicles. This is a combination of technological efficiency and behavioural change (e.g. access 
restrictions, ecological driving and adherence to speed limits). It would also include increasing load factors in both the passenger and freight sectors, where again there are substantial opportunities to use the new technologies creatively to match up journeys or loads to increase occupancy levels and to reduce the overall numbers of vehicles using the transport system.

The key to such a shift in thinking is the creation of spaces and localities in the city that are attractive and affordable, as neighbourhood quality is central to sustainable mobility. Transport planning must involve all stakeholders in the broadest sense, so that there is an understanding and acceptance of the rationale behind the policy changes, and an increased likelihood that behavioural change follows. Such involvement would help match expectations of behavioural change with actual outcomes, and this in turn may lead to permanent change with limited possibilities for rebound effects. Public acceptability is central to successful implementation of radical change, and it needs to involve community and stakeholder commitment to the process of discussion, decision making and implementation.

\section{Planning for City Futures}

Trying to unravel the complexities of the interrelationships between travel, urban form and sustainable development is difficult. Underlying the discussion is the requirement to have some vision of the city in its desired form - it should be viable (economic justification), have vitality (inclusive and fair), and it should be healthy (high quality of life and environmental quality). Transport provides an essential element in city viability, vitality and health. The EU vision is based on maintaining the quality of urban life, urban planning and sustainable development, where mixed uses, high densities and good environmental conditions are seen as being central to both improving economic performance and the vitality of cities.

This vision has resulted from the assessment of the substantial research that has tried to establish the links between travel, land use and urban form. This research ranges from simple analyses of trip generation and attraction characteristics of particular land uses (e.g. residential and shopping) to more detailed analyses of travel (and energy use) in locations with distinctly different characteristics. The verdict on this empirical work is mixed. For example, Anderson et al (1996) concluded that the current level of understanding of the influence of urban form on the generation of emissions and the use of energy is weak. But others (e.g. Stead, 2001 and Hickman, 2007) have found far more significant relationships between land use and transport. In both these cases, the socio economic variables explain substantially more of the variation in trip making activities than the land use factors. Underlying all the debates, three main elements need to be examined, namely the density of development, proximity and quality of development, and local neighbourhood and design factors (for a more detailed exposition see Banister and Anable, 2009).

Land use effects on travel behaviour tend to be cumulative and mutually reinforcing (Hickman, 2007; Litman, 2007). This effect can be illustrated in two ways. Ewing and Cervero (2002) calculated the elasticity of vehicle trips and travel per capita with respect to four land use variables (Table 4). Their estimates suggest that a doubling on local density reduces car trips by $5 \%$ per capita and travel by about the same amount. Although the elasticities are low, Ewing and Cervero (2002) concluded that they were cumulative, giving a total potential of $13 \%$ and $33 \%$ decreases in trips and trip distance (VMT) respectively. 
The second study was by Lawton (2001) using data from Portland Oregon to examine the impact of land use density, mix, and road network connectivity on personal travel. As these three urbanisation factors increase, per capita vehicle travel declines significantly from about 20 average daily travel miles per adult $(32 \mathrm{kms})$ to just over 6 miles (10kms).

From the extensive empirical work that has been carried out with respect to the impacts of the land use factors on travel distance, six main factors emerge (Banister and Hickman, 2006), and they are consistent with the sustainable mobility paradigm (Section 5). At the regional level, the location of new development, particularly housing, should be of a substantial size and located near to or within existing settlements so that the total population is at least 25,000 and probably nearer to 50,000. The provision of local facilities and services should be phased so as to encourage the development of local travel patterns. Secondly, density is important and average journey lengths by car are relatively constant (around $12 \mathrm{~km}$ ) at densities over 15 persons per hectare, but at lower densities car journey lengths increase by up to $35 \%$. Similarly, as density increases, the number of trips by car decreases from $72 \%$ of all journeys to $51 \%$. Car use in the high density locations is half that in the lowest density locations. Thirdly, mixed use developments should reduce trip lengths and car dependence. Although research here is limited and concentrates on the work journey, there is considerable potential for enhancing the proximity of housing to all types of facilities and services. Fourthly, as settlement size increases, the trips become shorter and the proportion of trips by public transport increases. Diseconomies of size appear for the largest conurbations as trip lengths increase to accommodate the complex structures of these cities. Fifthly, development should be located near to public transport interchanges and corridors so that high levels of accessibility for all can be provided. But this may also encourage long distance public transport commuting. Free flowing strategic highway networks are likely to encourage the dispersal and sprawl of development and stretch commuting. Finally, the availability of parking is a key determinant of whether a car is used or not and appropriate standards need to be linked to accessibility levels.

These conclusions have been confirmed in a report for the UK Commission for Integrated Transport (CfIT, 2009), where the six issues, as outlined above, have been extended to eleven factors that seem to be central when thinking about the role of spatial planning in contributing to sustainable development (Table 5). The UKERC (2009) has also produced a large review study of the options available for reducing carbon emissions from surface passenger transport, where each possibility is analysed according to their potential emissions saving, problems with implementation and their costs. The review concentrated on travel choices and vehicle choices, and their main conclusion was that behaviour could be influenced by a range of complementary policies and that carbon reductions can be achieved at a relatively low cost. Little was said in this study on the role that land use and spatial planning policies might play.

Litman (2007) has argued that in the US a 10-20\% cumulative total saving in VMT is possible through density and mixed design, and a further $20-40 \%$ is possible from regional decisions on the location of new development (Table 6). The figures in the UK are likely to be less, as the trip distances travelled are lower and there is already a much greater use of land use and development controls than in the US.

In the US there is a clear recognition that the car has provided the means for cities to spread, leading to extensive suburbanisation, longer travel distances and low densities 
(TRB, 2009). It is only recently that the costs of a car intensive lifestyle have become apparent, and it is now clear that compact, mixed use development has a beneficial effect on vehicle miles travelled (VMT) when it is combined with other policy measures, such as demand management (Table 7).

In the developed cities there is a key difference between the European and US traditions. In the European cities there is a history of strategic planning and the control of the land development process from the national to the local level, with clear priorities, responsibilities and controls. This strong planning environment has allowed cities to retain much of their historic structures and suburbanisation has also been controlled, and this has in turn meant that public transport has had a stronger role to play. In the US, much of the local zoning regulations restrict density levels and the mixing of land uses, and this presents a significant barrier to compact development (TRB, 2009). The potential for higher density developments in the US is highest in new and replacement developments in the inner suburbs, and at locations near to good quality highway and public transport interchanges. The local concerns over congestion, local taxes and property values take precedence over the wider issues relating to housing affordability and climate change.

Cities in developing countries are following the same path, with the affluent middle classes buying cars as soon as they can afford to, and the resulting consequences for congestion, safety and the quality of the environment that are imposed on all other people in the city. The more efficient public transport, motorbikes and bicycles are squeezed out to make way for the car, which then dominates much of the available urban space. An opportunity has been missed, as it suggests that the car dominated US city is the only future. The EU cities offer a different perspective, as much of the existing urban structure has been maintained and there has been considerable investment in public transport. However, there is still the problem of urban sprawl, where both the land use and travel patterns are based on car dependent lifestyles and much lower density levels (Banister, 2006).

Cities that currently have low levels of motorisation are changing out of all recognition. About half of the world's population now live in urban areas, and this is increasing as migration takes place and as more city jobs are created. The Asian Development Bank estimates that the population of Asian cities are increasing by 40 million annually (ADB, 2009). Urban densities will fall as a result of increasing wealth, declining household size, low density residential growth and central area redevelopment. Many of these cities were not built for the levels of traffic they are now experiencing. The inherent flexibility in the use of street space for markets, small industrial activities and social spaces is being replaced by traffic, so that the car can dominate. The car based mobility requires mass redevelopment of the existing city centre or its expansion to new areas so that the necessary capacity can be created. Such 'solutions' are costly and have substantial implications for social welfare, environmental quality and health. The new mega cities of the world are emerging, not as the models of sustainable development, but as replicas of the car dependent cities of the West.

The ADB (2009) report has tried to address these issues through the promotion of a sustainable urban transport paradigm that examines management, finance and policy through a wide ranging review. Their proposal is for a much more transparent process that is built on accessibility, with demand management being seen as a central issue together with strong land use policy. The strategy is based on looking at ways to 
avoid travel through shorter journeys and more accessible activities, to shift travel to public transport rather than the car, and to improve the efficiency of all forms of transport. The avoid-shift-improve nexus is similar to the sustainable mobility paradigm (Section 5).

There are two other key elements in the ADB (2009) proposals. There should also be a clear future city vision or spatial strategy that is affordable, adaptable and implementable, and this requires strong institutions and governance structures for the city. Secondly, policy effectiveness needs to be clearly explained and accepted by the full range of stakeholders, through their involvement in the process. This is a challenging agenda but one that must be addressed if cities are to become the real centres for sustainable development, as argued here.

The ownership of land in the city is the key factor in much of the discussion in this important paper (ADB, 2009). The case is made that for real change to take place, there needs to be direct intervention by city governments. It is only through stable public institutions that the location, scale and type of land development can be properly regulated and operated. Transport can be seen as part of that development where some of the benefits can be released through value capture. At present much of the land used by low income groups is negotiated through the informal and small landowners, hence the need for intervention and partnership. It is only when the twin issues of poverty alleviation and sustainable transport are seen to be complementary and moving in the same direction that progress will be made.

\section{Conclusions and Implications for Cities}

The scale of the challenge is enormous, but it must be tackled in all cities, particularly those that are vulnerable to growth and flooding (Table 2). But the pathways followed by those cities in developed and developing countries may be rather different, as each city has its own unique problems to overcome. The debate on what to do also seems to have been set in a rather narrow economic framework that limits the possible role that planning and the land development process can play. For example, the McKinsey report (December, 2007) set a carbon abatement cost at $\$ 50$ per tonne $\mathrm{CO}_{2} \mathrm{e}$, and

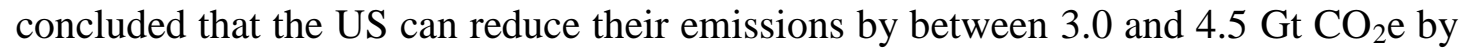
2030 (31\% to $49 \%$ reduction). About a third of this figure would come from action on the built environment (buildings) and transport, but it was assumed (p42) that there was no change in consumer utility. Urban design and denser, more transport efficient, communities were not assessed. It was also expected that there would be significant increases in distances travelled in the US over the period 2005-2030. The evidence cited here suggest that behavioural change and land use and development decisions can all have a substantial influence on travel and energy use, and must contribute to substantial reductions in $\mathrm{CO}_{2}$ emissions.

Although the empirical evidence may be limited, there is considerable potential for reducing the energy (carbon) use in transport in cities, through creative planning of new developments and the regeneration of existing areas. Sustainable development can be achieved through higher densities, high quality local environments, with close proximity to work and a range of services and facilities, in neighbourhoods that provide safety and security, so that the city can operate 24/7. Transport is designed out of much of the city, and where it is needed, priority is given to high quality public transport and cycling and walk. The role of the car in the city may be limited to ultra clean electric or plug-in hybrid vehicles powered by renewable energy. 
Apart from the lack of a clear vision and the seductiveness of following the high mobility option, there are two other key observations. One is that this option is extremely inequitable, as it favours the rich that can afford the new mobility, and it creates even greater problems for the mobility of other people. This is the classic situation where individual welfare is a much stronger force than societal welfare. The second is that to create change, there needs to be an alternative that is strongly supported by both the politicians and the public. Leadership and strong governance structures are essential, so that longer term priorities are matched up with short term gains, and that investment and positive actions can be taken consistently over time. Unfortunately, these key elements are often lacking in many cities.

This is the basic dilemma facing cities in terms of mobility and climate change. We all like travelling and we are doing much more of it. Yet we are also aware of the environmental costs of travelling and our responsibilities both locally and globally. Our social networks are increasingly international and the global economy is also dependent on long supply chains. To some extent individual behaviour can be modified and we can substitute travel with technological communication. But in many cases there is no substitute for face to face communication, and we want to see the world and to meet people. It presents a classic case of the conflict between individual preferences and choices, as opposed to the wider needs of society to protect the environment and future generations.

At present the scale and nature of the changes necessary in the transport sector to address climate change have not been seriously debated. Pricing for the external costs of transport would help, as would regulations on emissions and heavy investment in clean technology. But even here, the price rises necessary to create real change are not politically acceptable, as both industry and the electorate are powerful pro car lobbies. The real challenge confronting society is greater than this, namely the expected growth in travel from all cities and the desire for longer distance travel. Serious debate and action on these issues has not even started, and all the time the climate change clock is ticking.

\section{Acknowledgements}

Earlier versions of this paper have been presented at the Indian Institute of Technology, Delhi $2^{\text {nd }}$ Annual TRIPP Lecture (March 2009), and at the Royal Geographical Society with the Institute of British Geographers' Annual Conference in Manchester theme session on Transport and Climate Change (September 2009). Thanks also to two helpful referees.

\section{References}

Anderson, W, Kanaroglou, P and Miller, E (1996) Urban form, energy and the environment: a review of issues, evidence and policy, Urban Studies 33(10), pp. 7-35.

Asian Development Bank (ADB) (2009) Changing Course: A New Paradigm for Sustainable Urban Transport, Manila, ADB, August.

Banister, D (2005) Unsustainable Transport: City Transport in the New Century, London: Routledge.

Banister, D (2006) Transport, urban form and economic growth. Keynote paper for the JTRC/ECMT Round Table 137, Berkeley, California, March, pp. 113-142.

Banister, D (2008) The sustainable mobility paradigm, Transport Policy, 15(1), pp. 73-80. 
Banister, D and Anable, J (2009) Transport policies and climate change, in Davoudi, S. and Crawford, J. (eds) Planning for Climate Change: Strategies for Mitigation and Adaptation for Spatial Planners, London: Earthscan, pp. 55-69.

Banister, D and Hickman, R. (2006) How to design a more sustainable and fairer built environment: transport and communications, IEEE Proceedings of the Intelligent Transport System 153(4), pp. 276-291.

Banister, D and Marshall, S (2000) Encouraging Transport Alternatives: Good Practice in Reducing Travel, London: The Stationery Office.

Banister, D and Stead, D (2004) Impact of information and communications technology on transport, Transport Reviews 24(5), pp. 611-632.

Commission for Integrated Transport (CfIT) (2009) Planning for Sustainable Travel: Summary Guide, Report prepared for the CfIT by the Halcrow Group, Oxford Brookes University and the University of Oxford, October, www.plan4sustainabletravel.org

Committee on Climate Change (2008) Building a low-carbon economy - The UK's contribution to tackling climate change, London, December.

DeCicco, J and Fung, F (2006) Global warming on the road: The climate impact of America's automobiles, Washington: Environmental Defense, June, p31.

EC (2006) European Climate Change Change Programme - EU Action against Climate Change, Brussels, January.

http://europa.eu.int/comm/environment/climat/pdf/eu climate change progr.pdf

EC DG for Energy and Transport (2008) EU Energy and Transport in Figures 2007/2008, Luxembourg.

Ewing, R. and Cervero, R. (2002) Travel and the Built Environment - Synthesis, Transportation Research Record 1780, TRB Washington.

Hall, P and Pain, K (2006) The Polycentric Metropolis: Learning from Mega-City Regions in Europe, London: Earthscan.

Hickman, R. (2007) Reducing Travel by Design; A Micro Analysis of New Household Location and the Commute to Work in Surrey, Unpublished PhD Thesis, Bartlett School of Planning, University College London, November.

IPCC (2001) Climate Change: The Scientific Basis, Oxford: Oxford University Press, International Panel for Climate Change, www.ipcc.ch

IPCC (2007) Climate Change 2007: The Physical Science Base, Report for Policy Makers, Paris, February, http://www.ipcc.ch/SPM2feb07.pdf

Lawton, K.T. (2001) The Urban Structure and Personal Travel: An Analysis of Portland, Oregon Data and Some National and international Data, E-Vision Conference (www.rand.org/scitech/stpi/Evision/Supplement/lawton.pdf).

Litman, T.A. (2007) Land use impacts on transport: How land use factors affect travel behaviour, Victoria Transport Policy Institute, Canada, April.

Lyons, G and Kenyon, S (2003) Social participation, personal travel and Internet use, Proceedings of the $10^{\text {th }}$ International Conference on Travel Behaviour Research, Lucerne, August.

Marshall, S (2001) The challenge of sustainable transport, in Layard, A, Davoudi, S and Batty, S (eds) Planning for a Sustainable Future, London: Spon, pp. 131-147.

McKinsey and Company (2007) Reducing US Greenhouse Gas Emissions: How Much at what Cost? US Greenhouse Gas Abatement Mapping Initiative, December. 
Meinhausen, M. (2006) What does a 2C target mean for greenhouse gas concentrations? A brief analysis based on multi-gas emission pathways and several climate sensitivity uncertainty estimates, In Schellnhuber, HJ., Cramer, W, Nakicenovic, N., Wigley, T. and Gohe, G. (eds) Avoiding Dangerous Climate Change, Cambridge: Cambridge University Press, pp. 253-279.

Meyer, A (2001) Contraction and Convergence, London: Green Books, and available from the Global Commons Institute.

Nicholls, R.J., Hanson, S., Herweijer, C., Patmore, N., Hallegatte, S., Corfee-Morlot, J., Chateau, J. and Muir-Wood, R. (2008) Ranking Port Cities with High Exposure and Vulnerability to Climate Extremes, OECD, Environment Working Paper 1, ENV/WKP(2007) republished on 19 November 2008. www.oecd.org/env/workingpapers

Ribeiro, KS, Kobayashi, S, Beuthe, M, Gasca, J, Greene, D, Lee, DS, Muromachi, Y, Newton, PJ, Plotkin, S, Sperling, D, Wit, R and Zhou, PJ (2007) Transport and its Infrastructure. In Climate Change 2007: Mitigation. Contribution of Working Group III to the Fourth Assessment Report of the Intergovernmental Panel on Climate Change [B. Metz, O.R. Davidson, P.R. Bosch, R. Dave, L.A. Meyer (eds)], Cambridge University Press, Cambridge, United Kingdom and New York, NY, USA, pp. 325-385.

Society of Motor Manufacturers and Traders (SMMT) (2006) UK New Car Registrations by $\mathrm{CO}_{2}$ Performance, London, April.

Stead, D. (2001) Relationships between land use, socio-economic factors, and travel patterns in Britain. Environment and Planning B, 28(4), pp. 499-528.

Stern, N (2006) The Economics of Climate Change, Report for HM Treasury, London, October and also published by Cambridge University Press. http://www.hmtreasury.gov.uk/independent_reviews/stern_review_economics_climate_change/stern_review report.cfm

Transportation Research Board (TRB) (2009) Driving and the Built Environment: The Effects of compact Development on Motorized Travel, Energy Use and $\mathrm{CO}_{2}$ Emissions, Transportation Research Board Special Report 298, August.

UKERC (2009) What policies are effective at reducing carbon emissions from surface passenger transport? A review of interventions to encourage behavioural and technological change, UK Energy Research Centre.

UN Habitat (2008) State of the World's Cities 2008/2009: Harmonious Cities, UN Habitat Kenya: Nairobi. 
Table 1: EU27 energy consumption and GHG emissions in transport and growth in travel $(1990-2005$ - Data indexed to $1995=100)$

\begin{tabular}{|c|c|c|c|c|c|c|c|c|c|c|c|c|}
\hline EU27 & \multicolumn{2}{l|}{$\begin{array}{l}\text { Total energy } \\
\text { consumption in } \\
\text { transport (mtoe) }\end{array}$} & \multicolumn{2}{l|}{$\begin{array}{l}\text { GHG emissions } \\
\text { from transport } \\
\text { activities }\left(\mathrm{mtCO}_{2} \mathrm{e}\right)\end{array}$} & \multicolumn{2}{l|}{$\begin{array}{l}\text { Travel by car } \\
\text { (m pass km) }\end{array}$} & \multicolumn{3}{l|}{$\begin{array}{l}\text { All passenger travel } \\
\text { (m pass km) }\end{array}$} \\
\hline & 1990 & 2000 & 2005 & 1990 & 2000 & 2005 & 1990 & 2000 & 2005 & 1990 & 2000 & 2005 \\
\hline & 93 & 113 & 121 & 93 & 113 & 123 & 88 & 111 & 117 & 90 & 111 & 118 \\
\hline
\end{tabular}

Notes: 1. Total energy - all modes, including rail, road, air and inland navigation. 2. Aggregate emissions of Kyoto basket of $6 \mathrm{GHG}$ weighted by their global warming potentials. 3. All passenger transport includes car, bus, metro and rail, but not internal air, sea and powered two wheels.

Source: EC (2006) and EC DG for Energy and Transport (2008)

Table 2: Potential Impact of Climate Change on the Top 20 World Port Cities

\begin{tabular}{|c|c|c|c|}
\hline \multicolumn{2}{|c|}{2005} & \multicolumn{2}{|c|}{2070} \\
\hline $\begin{array}{c}\text { Top } 10 \text { cities by } \\
\text { exposed population }\end{array}$ & $\begin{array}{l}\text { Top } 10 \text { cities by } \\
\text { exposed assets }\end{array}$ & $\begin{array}{l}\text { Top } 10 \text { cities by } \\
\text { exposed population }\end{array}$ & $\begin{array}{l}\text { Top } 10 \text { cities by } \\
\text { exposed assets }\end{array}$ \\
\hline $\begin{array}{l}\text { Mumbai } \\
\text { Guangzhou } \\
\text { Shanghai } \\
\text { Miami } \\
\text { Ho Chi Minh City } \\
\text { Kolkata } \\
\text { New York-Newark } \\
\text { Osaka-Kobe } \\
\text { Alexandria } \\
\text { New Orleans } \\
\end{array}$ & $\begin{array}{l}\text { Miami } \\
\text { New York-Newark } \\
\text { New Orleans } \\
\text { Osaka-Kobe } \\
\text { Tokyo } \\
\text { Amsterdam } \\
\text { Rotterdam } \\
\text { Nagoya } \\
\text { Tampa-St Petersburg } \\
\text { Virginia Beach } \\
\end{array}$ & $\begin{array}{l}\text { Kolkata } \\
\text { Mumbai } \\
\text { Dhaka } \\
\text { Guangzhou } \\
\text { Ho Chi Minh City } \\
\text { Shanghai } \\
\text { Bangkok } \\
\text { Miami } \\
\text { Hai Phong (Vietnam) } \\
\text { Alexandria } \\
\end{array}$ & $\begin{array}{l}\text { Miami } \\
\text { Guangzhou } \\
\text { New York-Newark } \\
\text { Kolkata } \\
\text { Shanghai } \\
\text { Mumbai } \\
\text { Tianjin (China) } \\
\text { Tokyo } \\
\text { Bangkok } \\
\text { New Orleans } \\
\end{array}$ \\
\hline $\begin{array}{l}\text { These cities are split } \\
\text { almost equally } \\
\text { between developed } \\
\text { and developing } \\
\text { countries }\end{array}$ & $\begin{array}{l}\text { These } 10 \text { cities } \\
\text { account for } 60 \% \text { of } \\
\text { total exposure, and } \\
\text { are based in } 3 \\
\text { wealthy countries } \\
\text { (USA, Japan, and the } \\
\text { Netherlands). Total } \\
\text { exposed assets for all } \\
20 \text { cities is } \$ 3000 \\
\text { billion ( } 2005 \text { prices) } \\
\text { or } 5 \% \text { global GDP. }\end{array}$ & $\begin{array}{l}\text { The exposed } \\
\text { population has } \\
\text { increased by } 3 \text { times } \\
\text { to } 150 \mathrm{~m} \text { - almost all } \\
\text { the cities are in } \\
\text { developing countries. }\end{array}$ & $\begin{array}{l}\text { The total exposed } \\
\text { assts have increased } \\
\text { by } 10 \text { times to } \\
\$ 35,000 \text { billion }(2005 \\
\text { prices) or } 9 \% \text { of } \\
\text { global GDP }\end{array}$ \\
\hline
\end{tabular}

Note: The main driving forces of the 2070 Scenarios are population growth, economic growth and urbanisation, and these factors are exacerbated by climate change (sea level rises and increased storminess) and subsidence.

Source: Based on Nicholls et al., 2008 
Table 3: Contrasting Approaches to Transport Planning

\begin{tabular}{|l|l|}
\hline The Conventional Approach & An Alternative Approach \\
Transport Planning and Engineering & Sustainable Mobility \\
\hline Physical dimensions & Social dimensions \\
Mobility & Accessibility \\
Traffic focus, particularly on the car & People focus, either in (or on) a vehicle or on foot \\
\hline Large in scale & Local in scale \\
Street as a road & Street as a space \\
Motorised transport & All modes of transport often in a hierarchy with \\
& pedestrian and cyclist at the top and car users at the \\
& bottom \\
\hline Forecasting traffic & Visioning on cities \\
Modelling approaches & Scenario development and modelling \\
Economic evaluation & Multicriteria analysis to take account of environmental \\
& and social concerns \\
\hline Travel as a derived demand & Travel as a valued activity as well as a derived demand \\
Demand based & Management based \\
Speeding up traffic & Slowing movement down \\
Travel time minimisation & Reasonable travel times and travel time reliability \\
Segregation of people and traffic & Integration of people and traffic \\
\hline
\end{tabular}

Source: Adapted from Marshall (2001), Table 9.2.

Table 4: Elasticities of Trips and Travel by Land use Factors

\begin{tabular}{|c|c|c|c|}
\hline Factor & Description & Trips & $\begin{array}{l}\text { Travel } \\
(\text { VMT) }\end{array}$ \\
\hline Local density & Residents and employees divided by land area & -0.05 & -0.05 \\
\hline Local diversity & Jobs/residential population & -0.03 & -0.05 \\
\hline Local design & $\begin{array}{l}\text { Sidewalk completeness/route directness and street } \\
\text { network density }\end{array}$ & -0.05 & -0.03 \\
\hline Regional accessibility & Distance to other activity centres in the region & - & -0.20 \\
\hline
\end{tabular}

Source: Ewing and Cervero (2002)

Table 5: Planning for Sustainable Travel - UK Evidence

\begin{tabular}{|l|l|l|}
\hline 1. Settlement size & 5. Jobs-housing balance & $\begin{array}{l}\text { 9. Neighbourhood design and } \\
\text { street layout }\end{array}$ \\
$\begin{array}{l}\text { 2. Strategic development } \\
\text { location }\end{array}$ & $\begin{array}{l}\text { 6. Accessibility to key } \\
\text { facilities }\end{array}$ & $\begin{array}{l}\text { 10. Traffic demand } \\
\text { management } \\
\text { 3. Strategic transport network }\end{array}$ \\
$\begin{array}{l}\text { 7. Development site location } \\
\text { 4. Mensity }\end{array}$ & \begin{tabular}{l} 
11. Parking and servicing \\
\hline
\end{tabular} \\
\hline
\end{tabular}

Based on CfIT (2009) 
Table 6: Land Use Impacts on Transport - US Evidence

\begin{tabular}{|c|c|c|}
\hline Factor & Definition & Travel Impacts \\
\hline $\begin{array}{l}\text { 1. Regional } \\
\text { Accessibility }\end{array}$ & $\begin{array}{l}\text { Location of development } \\
\text { relative to regional urban } \\
\text { centres }\end{array}$ & $\begin{array}{l}\text { Improved accessibility reduces per capita vehicle } \\
\text { mileage. Residents of more central } \\
\text { neighbourhoods typically drive } 10-30 \% \text { fewer } \\
\text { miles than urban fringe residents. }\end{array}$ \\
\hline 2. Density & $\begin{array}{l}\text { People or jobs per unit } \\
\text { of land area }\end{array}$ & $\begin{array}{l}\text { Increased density tends to reduce per capita } \\
\text { vehicle travel. Each } 10 \% \text { increase in urban } \\
\text { densities typically reduces per capita VMT by } 1- \\
3 \% \text {. }\end{array}$ \\
\hline 3. Mix & $\begin{array}{l}\text { Degree that related land } \\
\text { uses are located close } \\
\text { together }\end{array}$ & $\begin{array}{l}\text { Increased land use mix tends to reduce per capita } \\
\text { vehicle travel and increase the use of alternative } \\
\text { modes, particularly walking. Neighbourhoods } \\
\text { with good land use mix typically have 5-15\% } \\
\text { lower vehicle miles. }\end{array}$ \\
\hline $\begin{array}{l}\text { 4. Public Transport } \\
\text { Accessibility, } \\
\text { Walking and } \\
\text { Cycling Conditions }\end{array}$ & $\begin{array}{l}\text { Quality of public } \\
\text { transport and degree to } \\
\text { which destinations are } \\
\text { accessible; Quantity, } \\
\text { quality and security of } \\
\text { walking and cycling }\end{array}$ & $\begin{array}{l}\text { Residents with good access to public transport } \\
\text { tend to own } 10-30 \% \text { less cars, drive } 10-30 \% \\
\text { fewer miles, and use alternative modes } 2-10 \text { times } \\
\text { more frequently than residents in car oriented } \\
\text { developments. Residents in more walkable } \\
\text { communities walk } 2-4 \text { times as much and drive 5- } \\
15 \% \text { less than if they lived in more car oriented } \\
\text { developments. }\end{array}$ \\
\hline $\begin{array}{l}\text { 5. Centredness, } \\
\text { Network } \\
\text { Connectivity, } \\
\text { Design and } \\
\text { Management of } \\
\text { Routes }\end{array}$ & $\begin{array}{l}\text { Location of employment } \\
\text { in major activity centres, } \\
\text { connectivity of the } \\
\text { network (including } \\
\text { density), design and } \\
\text { layout of streets }\end{array}$ & $\begin{array}{l}\text { Typically } 30-60 \% \text { of commuters to major } \\
\text { commercial centres use alternative modes, } \\
\text { compared with } 5-15 \% \text { of commuters at dispersed } \\
\text { locations. Better road connectivity can reduce } \\
\text { vehicle mileage and better cycling and walking } \\
\text { provision also helps these modes. More multi } \\
\text { modal streets improves use of alternative modes, } \\
\text { with traffic calming reducing car use and } \\
\text { increasing walking and cycling. }\end{array}$ \\
\hline $\begin{array}{l}\text { 6. Parking Supply } \\
\text { and Management } \\
\text { and Site Design }\end{array}$ & $\begin{array}{l}\text { Number of spaces per } \\
\text { unit area, costs, time } \\
\text { limits and management, } \\
\text { and layout } \\
\text { considerations }\end{array}$ & $\begin{array}{l}\text { Parking management strategies can significantly } \\
\text { reduce car ownership and mileage. Cost recovery } \\
\text { pricing reduces car trips by } 10-30 \% \text {. Mobility } \\
\text { management can also reduce car trips by } 10-30 \% \text {. }\end{array}$ \\
\hline
\end{tabular}

Based on Litman (2007), Table 21. 
The most reliable studies estimate that doubling the residential density across a metropolitan area might lower household VMT by $5-12 \%$, and perhaps by as much as $25 \%$, if coupled with high employment concentrations, significant public transit improvements, mixed uses and other supportive demand management measures.

More compact, mixed use development can produce reductions in energy consumption and $\mathrm{CO}_{2}$ emissions both directly and indirectly

Significant increases in more compact, mixed use development result in only modest short term reductions in energy consumption and $\mathrm{CO}_{2}$ emissions, but these reductions will grow over time.

If $75 \%$ of new and replacement housing units are built in more compact development (effectively doubling densities) and the residents of compact communities drive $25 \%$ less, VMT and associated fuel use and $\mathrm{CO}_{2}$ emissions of new and existing households would be reduced by $7-8 \%$ relative to base conditions by 2030 and by $8-11 \%$ by 2050 . But there was some concern about whether such a substantial change was feasible.

Based on TRB (2009) 